\title{
GAYA KEPEMIMPINAN TRANSFORMASIONAL PADA PERPUSTAKAAN PERGURUAN TINGGI RISET
}

\author{
Sapto Harmoko \\ Mahasiswa Pascasarjana Jurusan Ilmu Perpustakaan \\ UIN Sunan Kalijaga Yogyakarta
}

Di era generasi milenial ini Perpustakaan Perguruan Tinggi Riset lebih mengedepankan kepada komunikasi ilmiah. Perpustakaan perguruan tinggi riset telah mengalami pergeseran paradigma, mengalami perkembangan, dan bertransformasi seiring dengan perkembangan ilmu pengetahuan dan penelitian. Gaya kepemimpinan yang sesuai dengan perubahan tersebut adalah gaya kepemimpinan transformasional karena gaya kepemimpinan tersebut mampu mengikuti perkembangan informasi, kemajuan teknologi, tuntutan profesionalisme kerja, dan perubahan karakter pemustaka. Gaya kepemimpinan tranformasional sangat diminati oleh perpustakaan tinggi riset karena mampu menyesuaikan diri dengan transformasi yang terjadi antara lain restrukturisasi organisasi, mengetahui pengetahuan tentang anggaran, manajemen personalia, selalu belajar baik untuk menjadi fasilitator maupun aktor dalam organisasi, mampu memilih staf yang tepat.

Kata Kunci: Perpustakaan, Gaya kepemimpinan tranformasional

\section{Pendahuluan \\ Latar Belakang}

Sebagai makhluk sosial, manusia tidak dapat hidup sendiri, mereka akan selalu berinteraksi dengan manusia lainnya dalam sebuah struktur organisasi atau komunitas masyarakat. Seluruh aktivitas manusia yang berhubungan dengan organisasi dalam struktur masyarakat tersebut serta segala urusan ketatalaksanaannya tidak dapat dilepaskan dari kebutuhan akan seorang pemimpin yang akan membawa mereka ke dalam suatu tujuan yang dicita-citakan. Seseorang akan dipilih sebagai seorang pemimpin oleh anggota kelompok apabila dirinya dipandang mampu dan dianggap memiliki berbagai kriteria jiwa kepemimpinan, seperti kewibawaan, kebijaksanaan, kepandaian atau keilmuan, keadilan, dan sebagainya.

Dalam praktek dunia organisasi, kepemimpinan sangat mudah ditemukan dalam berbagai lingkup dan level organisasi, seperti dalam organisasi pemerintahan level tertinggi dapat dijumpai adanya kepala, kepala bidang (kabid), kepala bagian (kabag), kepala subbagian (kasubag), hingga level paling rendah seperti kepala seksi (kasie) maupun penanggung jawab (Pj). Pada organisasi BUMN, BHMN, dan organisasi sejenis dapat ditemui jabatan seperti Direktur, Wakil Direktur, Kepala Unit, Kepala Cabang, hingga kepala divisi dan kepala sub divisi. Dalam bidang sosial kemasyarakatan dikenal adanya ketua RW, Ketua $\mathrm{RT}$, kepala suku, kepala atau pemangku adat, kepala keamanan, dan sejenisnya.

Dari berbagai sebutan untuk berbagai level kepemimpinan tersebut, pada dasarnya terdapat sebuah catatan bahwa pada level mana pun seorang pemimpin tersebut berada, gaya kepemimpinan yang tepat sangat bergantung kepada kriteria seorang pemimpin, hubungannya dengan pihak-pihak yang terlibat, sifat yang dimiliki, serta bagaimana dia menyelesaikan kesulitan yang dihadapi melalui kompetensi yang dimiliki.

Saat ini perkembangan organisasi dalam masyarakat mengalami perkembangan seiring dengan perubahan sosial kemasyarakatan, lingkungan, sikap dan perilaku anggota organisasi. Juga didorong adanya persaingan atau kompetisi antar organisasi yang semakin ketat, maupun perkembangan dalam bidang teknologi informasi 
dan komunikasi yang semakin canggih. Perkembangan tersebut berimbas kepada organisasi yang bergerak dalam bidang informasi, seperti perpustakaan perguruan tinggi yang dalam tiga dekade terakhir telah mengalami perubahan dalam layanan, konstruksi organisasi, maupun teknologi yang dipergunakan (Gwyer, 2010).

Munculnya generasi milenial yang dipengaruhi oleh teknologi telepon pintar (smartphone), gadget serta peralatan hi-tech lainnya, hingga perkembangan internet, telah membawa perubahan terhadap perilaku masyarakat akan akses informasi (Fatmawati, 2010). Perubahan tersebut telah mengakibatkan adanya pergeseran paradigma dalam dunia perpustakaan dan informasi, diantaranya (Fatmawati, 2010):

1. Kebebasan akses informasi yang bersumber dari internet

2. Hilangnya sekat-sekat birokrasi dan formalitas yang selama ini dipertahankan oleh lembaga perpustakaan

3. Perpustakaan sebagai pusat belajar masyarakat

4. Pergeseran dari paradigma lama sebagai gedung yang terkesan kaku dan feodal menjadi fasilitas yang memiliki interior bernilai artistik.

5. Pemustaka lebih memahami teknologi yang sedang berkembang atau dapat disebut sebagai melek teknologi

6. Ketersediaan fasilitas-fasilitas pendukung bagi pemustaka yang sedang berkunjung atau belajar di perpustakaan

7. Penyederhanaan alur pelayanan maupun peraturan dalam akses pelayanan di perpustakaan

8. Perpustakaan telah dilengkapi dengan backup teknologi seperti RFID, sensor, dan single sign on sehingga berbagai larangan terhadap pemustaka seperti tidak boleh membawa buku atau stopmap dari luar perpustakaan menjadi lebih longgar
9. Perpustakaan harus terus mengembangkan diri dengan inovasi teknologi informasi terbaru, meliputi infrastuktur dan fasilitasnya, membangun link dan jejaring dengan perpustakaan lain, serta memperbanyak melanggan e-journal dan e-books.

Perpustakaan perguruan tinggi riset mengedepankan kepada komunikasi ilmiah/ scientific communications. Dalam hal ini seorang peneliti akan memanfaatkan dan menyebarkan informasi di lingkungan akademiknya baik melalui media rekam formal seperti buku, artikel jurnal, prosiding, dan publikasi ilmiah lainnya, maupun komunikasi informal seperti seminar atau diskusi ilmiah, ceramah, telepon, surat menyurat, dan sebagainya (Siswadi, 2009). Perpustakaan perguruan tinggi riset mempunyai peranan yang cukup besar dalam scholarly communication tersebut diantaranya terkait dengan pembangunan dan pemanfaatan repositori dan kebijakan akses (Siswadi, 2009). Perpustakaan perlu menyediakan tempat penyimpanan (repositories) dan akses terbuka (open access) terhadap karya ilmiah yang dihasilkan oleh para peneliti pada perguruan tinggi tersebut.

Berdasarkan latar belakang di atas, berbagai kebijakan yang mampu mendukung perpustakaan perguruan tinggi riset sebagai sarana dalam komunikasi ilmiah perlu ditetapkan. Sebagai contoh, kebijakan open access versus ownership, kebijakan berjejaring antar perpustakaan, isu plagiat, dan sebagainya. Untuk menentukan arah kebijakan tersebut, diperlukan seorang pemimpin yang peka terhadap perkembangan yang ada. Seperti apakah gaya kepemimpinan pada perpustakaan perguruan tinggi riset?

Beberapa ahli telah menawarkan berbagai macam gaya kepemimpinan, dalam makalah ini akan menganalisis gaya kepemimpinan yang disampaikan oleh Kumaran (Kumaran, 2012) yang paling sesuai untuk perpustakaan perguruan tinggi riset. 


\section{Landasan Teori}

Gaya Kepemimpinan

Kepemimpinan meliputi bagaimana mempengaruhi, memobilisasi, memotivasi, menginspirasi, dan memberikan peluang kepada seluruh anggota organisasi untuk mencapai potensi mereka secara maksimal. Agar hal tersebut dapat terwujud secara efektif seorang pemimpin harus selalu belajar atau mempersiapkan diri terkait dengan gaya kepemimpinan yang akan diambil dan keterampilan yang akan dipergunakan dalam berbagai situasi. Seorang pemimpin yang tidak memiliki gaya kepemimpinan tidak akan sukses dalam membantu seluruh anggota organisasi untuk mencapai potensi mereka dan akibatnya dia tidak akan sukses memimpin sebuah organisasi. Budaya organisasi dan ekspektasi terhadap anggota yang dipimpinnya mengharuskan seorang pemimpin untuk mengadopsi sebuah gaya kepemimpinan. Gaya kepemimpinan merupakan sebuah cara seorang pemimpin untuk bertindak. Gaya kepemimpinan dapat mencakup (Kumaran, 2012):

1. Faktor fisik, yang meliputi bahasa tubuh (body language), nada bicara atau suara (voice), kontak mata (eye contact), dan kata-kata yang digunakan.

2. Faktor karakteristik yang diperlihatkan dari sifat kerendahan hati, kecerdasan, atau intelektualitas.

Gaya yang akan dipergunakan oleh seorang pemimpin tergantung pada nilai individu, keyakinan, latar belakang budaya, latar belakang organisasi, dan kepribadian. Dengan demikian tidak mudah untuk merumuskan gaya kepemimpinan mana yang paling baik yang dapat diterapkan untuk semua organisasi karena gaya kepemimpinan sangat bergantung pada nilai-nilai di atas. Terkait dengan hal tersebut beberapa ahli merumuskan berbagai gaya kepemimpinan, diantaranya menurut Northouse, P.G dalam Reeder yang memuat sepuluh gaya kepemimpinan yaitu: autocratic, bureauctaric, democratic, laissez-faire, charismatic, transformational, transactional, strategic, delegative, dan authoritarian (Reeder, 2012). Sedangkan menurut Siagian dalam Sugiyanti (2012), menyebutkan terdapat lima gaya kepemimpinan yaitu: otokratik, paternalistik, kharismatik, demokratik, dan laissez-faire. Daniel Coleman dalam Kumaran, memaparkan terdapat enam gaya kepemimpinan pada lembaga perpustakaan, yaitu: coercive, authoritative, affliative, democratic, pace setting, dan coaching (Kumaran, 2012).

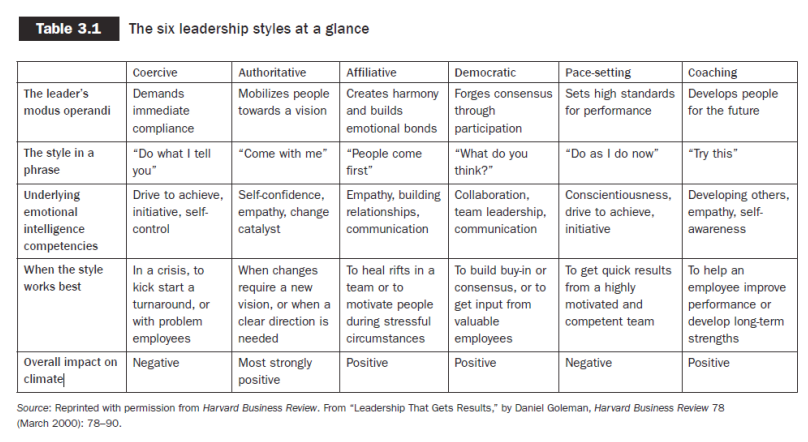

Bagan 1. Enam Gaya Kepemimpinan

Sedangkan gaya kepemimpinan menurut teori kepemimpin yang terbaru meliputi (Kumaran, 2012):

a. Kepemimpinan transformasional (transformational leadership)

Kepemimpinan transformasional mengacu kepada seperangkat kemampuan yang memungkinkan seorang pemimpin untuk mengenali kebutuhan akan perubahan. Gaya kepemimpinan ini menekankan kepada tingginya pengembangan motivasi dan kemauan yang kuat dari para anggota organisasi dengan cara menciptakan visi dan misi yang inspiratif untuk masa depan organisasi. (J. Rowold dan A. Rohmann, 2009), Ada tiga tujuan dalam kepemimpinan transformasional, meliputi:

1. Membantu staf atau anggota organisasi mengembangkan dan mempertahankan 
budaya kolaboratif dan profesionalisme untuk mendukung perubahan yang terjadi.

2. Mampu secara aktif mengkomunikasikan norma-norma dalam organisasi dan menumbuhkan keyakinan atau kepercayaan kepada staf atau anggota organisasi.

3. Mampu membantu menyelesaikan permasalahan yang terjadi dalam organisasi secara efektif.(Reeder, 2014)

Pemimpin dengan gaya transformasional merupakan agen perubahan karena mereka mampu menginspirasi anggota organisasi untuk berkesempatan menjadi pemimpin itu sendiri, memacu pertumbuhan atau perkembangan keperibadian dan profesionaitas para anggota organisasi (Reeder, 2014). Seorang pemimpin dengan gaya transformasional memiliki keyakinan yang mendalam tentang apa yang ingin dicapai oleh organisasi, siap untuk melawan kebijakan konvensional, memiliki tekad untuk membuat sesuatu atau berinovasi, mendorong orang lain untuk mencari peluang, dan dia akan berbagi dengan anggota oraganisasi terkait ambisi, keinginan atau cita-cita yang akan dicapai

b. Kepemimpinan transaksional (transactional leadership)

Kepemimpinan transaksional terkait dengan bagaimana seorang pemimpin mempertahankan stabilitas dalam sebuah organisasi. Dia dapat bekerja dengan perubahan dan bahkan mungkin berkembang dalam lingkungan perubahan tersebut. Akan tetapi seorang pemimpin dengan gaya transaksional tidak selalu nyaman dengan perubahan di lingkungannya dan tidak menjadi pemimpin terbaik dalam mengelola perubahan tersebut.

c. Kepemimpinan karismatik (charismatic leadership)
Kepemimpinan karismatik sangat bergantung pada daya tarik kepribadian si pemimpin. Karisma bisa jadi merupakan sifat penting bagi seorang pemimpin, namun tidak semua pemimpin yang sukses lantas menjadi seorang pemimpin yang karismatik. Namun belum tentu kepemimpinannya itu berkualitas atau berkemampuan akan tetapi mungkin hanya kepribadian mereka yang penuh karisma atau menyenangkan. Menjadi seorang yang berkarisma merupakan kualitas bawaan, dan tidak selalu harus dipelajari sehingga dapat disejajarkan dengan teori kepemimpinan Great Man. Pemimpin karismatik pada umumnya banyak dijumpai pada dunia politik maupun dunia hiburan.

d. Kepemimpinan virtual/ maya (virtual leadership)

Kepemimpinan virtual merupakan gaya kepemimpinan yang dapat dikatakan cukup baru. Gaya tersebut dimanfaatkan dalam sebuah organisasi dengan demografi, meliputi tenaga outsourcing dan kontraktor dari berbagai posisi di beberapa negara. Dengan demikian kepemimpinan virtual membutuhkan keterampilan untuk dapat bekerja dengan orang dari negara berbeda bahkan benua berbeda, zona waktu berbeda, budaya berbeda, dan diberbagai situasi pekerjaan. Gaya kepemimpian virtual mungkin akan menghadapi situasi tertentu seperti tidak adanya peralatan yang dimiliki oleh seluruh negara atau mungkin menghadapi hari libur, situasi politik yang mengakibatkan pekerjaan tidak dapat diproses pada saat itu. Seorang pemimpin virtual haruslah seorang yang berpengetahuan luas tentang etos kerja dan budaya kerja dari kelompok yang berbeda, mengenal situasi politik, mengetahui peraturan atau permasalahan hukum dalam berbagai lokasi. Pemimpin ini akan banyak 
bergantung pada aktivitas surat elektronik maupun komunikasi melalui telepon di mana bahasa tubuh/ body language tidak nampak oleh pendengarnya, sehingga pemimpin virtual perlu memiliki kemampuan komunikasi yang hebat.

\section{Perpustakaan Perguruan Tinggi Riset}

Kegiatan penelitian merupakan ciri dari perguruan tinggi riset. Adapun arti penting penelitian pada perguruan tinggi adalah sebagai berikut (Santoso, 2012).
a. Perguruan tinggi merupakan sumber penting dalam penelitian dan pengembangan.
b. Pembelajaran sarjana adalah kegiatan utama perguruan tinggi yang memungkinkan perguruan tinggi berhasil melaksanakan penelitian maju (advanced research) dan pendidikan pasca sarjana

Oleh karena itu sebuah perpustakaan perguruan tinggi riset mempunyai peran dalam komunikasi ilmiah. Perpustakaan menyediakan informasi yang akan dimanfaatkan oleh peneliti dalam proses riset mereka. Peneliti tersebut akan melakukan proses riset yang hasil kajiannya akan dikelola kembali oleh perpustakaan untuk dikomunikasikan dengan peneliti lainnya (penyebaran informasi), dapat digambarkan pada bagan berikut.

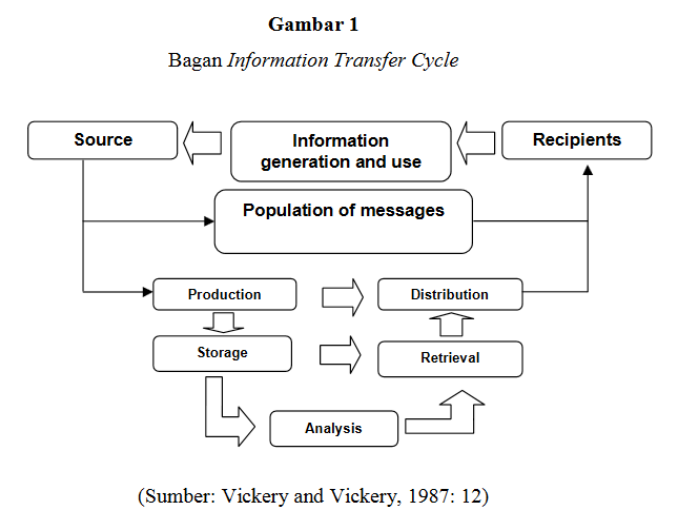

Bagan 2. Information Transfer Cycle (Brian Vickery dan Alina Vickery, 1987)
Siklus transfer informasi melibatkan tidak saja produsen (source) dan pengguna (recipient) informasi dalam masyarakat tetapi juga dalam ranah akademis (ilmiah) dan pekerja professional. Proses transfer informasi yang dimaknai sebagai pertukaran pesan (komunikasi) melibatkan sub komponen produksi (production), distribusi (distribution), penyimpanan (storage), penelusuran (retrieval) dan analisis (analysis) (Kurniawan, 2011). Dari berbagai komponen tersebut jelas terlihat posisi atau peran perpustakaan dalam komunikasi tersebut.

\section{Analisis}

Dalam komunikasi ilmiah diperlukan sumber informasi. Seorang peneliti akan memerlukan sumber informasi atau rujukan dari literatur atau penelitian dari peneliti lain. Ketersediaan sumbersumber tersebut di perpustakaan perguruan tinggi riset mutlak diperlukan. Ketersediaan sumber informasi meliputi:

1. Mendigitalkan koleksi-koleksi khusus.

Telah banyak perpustakaan perguruan tinggi yang melakukan digitalisasi dan hasilnya adalah ketersediaan terbuka dan mudah diakses atas konten-konten penting. Pemustaka tidak harus bersusah payah datang ke perpustakaan yang jauh dari lokasi mereka. Digitalisasi koleksi khusus juga memiliki tujuan sebagai sarana penyimpanan arsip.

2. Membangun Repositori.

Repositori dibangun untuk memberikan akses dan penyimpanan atau pengarsipan dokumen digital dan data yang dihasilkan dari penelitian yag dilakukan di perguruan tinggi.

3. Menyediakan infrastruktur.

Infrastruktur disediakan untuk membuka akses terhadap informasi, khususnya yang bersumber dari jurnal ilmiah.

(Lewis, 2000).

Dengan demikian perpustakaan perguruan tinggi riset dapat dikatakan menjadi lembaga yang 
memiliki peran yang kompleks. Untuk itu harus selalu membentuk kembali atau mentransformasikan diri dan memperbaharui diri menyesuaikan dengan perkembangan ilmu pengetahuan dan penelitian. Pustakawan perguruan tinggi riset harus mampu menunjukkan bahwa mereka mempunyai nilai dan peran penting. Perpustakaan harus mampu menarik minat pemustaka, memfasilitasi, dan mengedukasi pemustaka mereka untuk menjadi seorang generasi pembelajar sepanjang hayat. Pustakawan perpustakaan perguruan tinggi riset harus mampu mendukung penelitian yang dilakukan oleh seluruh sivitas akademika perguruan tinggi, dan mampu meningkatkan reputasi lembaganya. Keterbatasan anggaran, perubahan teknologi, dan petugas perpustakaan yang kurang kompeten sering menjadikan tantangan bagi kepala perpustakaan perguruan tinggi riset. Untuk itu perlu upaya dalam restrukturisasi pada perpustakaan perguruan tinggi riset untuk mengurangi kendala tersebut. Dengan demikian akan terbentuk budaya organisasi baru sehingga budaya kerja yang baru akan terakomodasi. Oleh karena itu diperlukan seorang pemimpin yang mampu menggerakkan orang-orang yang bekerja di perpustakaan untuk selalu belajar dan mampu memimpin atau mempersiapkan diri terhadap perubahan tersebut.

Gaya kepemimpinan perintah dan kontrol (command and control) sangat akrab di telinga kita yang bekerja di bidang perpustakaan (Olson dan Singer, 2004). Gaya kepemimpinan tersebut dapat dikatakan produk jaman dulu dimana unsur-unsur tertentu dari komando dan kontrol masih dimanfaatkan untuk memastikan tercapainya tujuan organisasi (Olson dan Singer, 2004). Akan tetapi perkembangan yang terjadi pada perpustakaan perguruan tinggi riset yang sangat kompleks dan dinamis memunculkan situasi dan tantangan yang tidak mampu diselesaikan dengan cara tersebut. Perlu dikembangkan sebuah cara yang memungkinkan perpustakaan perguruan tinggi riset untuk mampu memimpin organisasinya dengan cara yang berbeda, membangun kemitraan, berkolaborasi, demi peningkatan layanan kepada pemustaka.

Gaya kepemimpinan transformasional sangat diminati untuk jenis perpustakaan perguruan tinggi riset karena perpustakaan tersebut saat ini mengalami perubahan yang sangat besar dalam penyampaian informasi, tuntutan profesionalisme kerja, dan perubahan karakter penggunannya. Perubahan transformasional merupakan salah satu strategi yang sangat mungkin dilakukan demi peningkatan kinerja.

Perubahan peran kepemimpinan perpustakaan perguruan tinggi riset dapat dijelaskan sebagai berikut:

1. Kepemimpinan perpustakaan perguruan tinggi riset perlu memiliki ciri dan kombinasi dari berbagai sifat dimana hal tersebut tercantum dalam kriteria pemimpin dengan gaya transformasional.

2. Kepemimpinan yang sukses adalah pemimpin yang selalu memiliki perilaku untuk selalu belajar.

3. Selalu melibatkan anggota oraganisasi dalam pengambilan keputusan sehingga mereka lebih paham akan permasalahan yang ada, mereka akan lebih mampu melaksanakan keputusan, dan lebih berkomitmen untuk tindakan yang dilakukan ketika mereka dilibatkan dalam pengambilan keputusan yang relevan.

Pemimpin dengan gaya transformasional mampu melakukan berbagai tindakan untuk menyesuaikan diri dengan transformasi yang terjadi di perpustakaan, diantaranya (Reeder, 2014) :

1. Restrukturisasi organisasi

Pemimpin dengan gaya transformasional mengetahui adanya pendelegasian tugas, menerapkan kemajuan teknologi informasi, dan menyadari bahwa pemimpin tidak lagi berdiri dipuncak hirarki organisasi namun 
anggota adalah mitra kerja.

2. Memiliki pengetahuan tentang penganggaran, manajemen personalia, fundraising (creative funding/ mampu mencari peluang untuk mendapatkan sponsor dana). Pemimpin dengan gaya transformasional mengerti akan kegiatan inti perpustakaan. Namun demikian perlu dilengkapi dengan pemahaman keterampilan khusus yaitu kepekaan terhadap kebutuhan akan lingkungan perpustakaan yang baru atau selalu up-date status.

3. Pemimpin adakalanya mengeluh tentang perubahan teknologi informasi. Pemimpin dengan gaya transformasional harus mengerti bahwa perubahan adalah baik, harus dikelola, dan melihatnya sebagai sebuah inspirasi. Pendapat tersebut sangat sesuai bahwa perpustakaan perguruan tinggi riset saat ini membutuhkan visi dan pemimpin harus dapat mengkomunikasikan kepada anggota organisasi dan pemustaka. Pemimpin dengan gaya transformasional selalu belajar untuk menjadi fasilitator maupun aktor dalam organisasi.

4. Pemimpin dengan gaya transformasional mampu memilih staf yang tepat untuk menangani sebuah pekerjaan. Tradisi gaya perintah dan kontrol terhadap staf atau anggota organisasi telah mengalami perubahan dan hal tersebut tercermin dalam struktur organisasi yang lebih datar dan lebih menekankan pada administrasi yang besifat kolaboratif atau prinsip kerjasama.

Pemimpin dengan gaya transformasional, akan mampu menciptakan lingkungan kerja yang lebih baik. Lingkungan kerja yang kondusif akan mampu memberikan layanan yang lebih maksimal kepada pemustaka.

\section{Simpulan}

Dari uraian latar belakang dan pembahasan di atas, dapat diambil simpulan sebagai berikut:

1. Perpustakaan perguruan tinggi riset telah mengalami pergeseran paradigma, mengalami perkembangan, dan bertransformasi seiring dengan perkembangan ilmu pengetahuan dan penelitian.

2. Gaya kepemimpinan yang sesuai dengan perubahan tersebut adalah gaya kepemimpinan transformasional. Gaya kepemimpinan ini mampu mengikuti perkembangan informasi, kemajuan teknologi, tuntutan profesionalisme kerja, dan perubahan karakter penggunanya.

\section{Daftar Pustaka}

Fatmawati, Endang, 2010. “Pergeseran Paradigma Perpustakaan Generasi Millenial". Dalam Visi Pustaka, Volume 12, Nomor 2. Dalam http://digilib.undip.ac.id/v2/2012/06/05/ pergeseran-paradigma-perpustakaangenerasi-millennial, Tanggal 14 Juli 2017, pukul 10.05

Gwyer, R., 2010. "Leading in Difficult Times: What Can We Learn From The Literature?" Dalam New Review of Information Networking, Vol. 15, No. 1, Hal 4.

Kumaran, Maha. 2012. Leadership in Libraries: a Focus on Etnic Minority Librarians, Oxford: Chandos Publishing.

Kurniawan, Amin Taufiq. 2011. “Konsep Komunikasi Ilmiah Dalam Pemanfaatan Informasi di Perpustakaan dan Dokumentasi", Dalam Jurnal Komunikasi Massa Volume 4 Nomor 1. Dalam http://jurnalkommas.com/docs/ jurnal\%20pak\%20Amin\%20 Undip.pdf. Tanggal 27 Juli 2016. Pukul 08.00.

Lewis, David W. 2008. "Library Budget, Open Acces, and the Future Scholarly Communication", dalam College and Research Library News. Dalam http://crln.acrl.org/content/69/5/271.full. pdf+html. Tanggal 27 Juli 2017. Pukul 08.27.

Olson, Christi A. dan Singer, Paula M. 2004. Winning 
with Library Leadership. Chicago: American Library Association.

Reeder, Lizzie A. 2014. The Impact of Leadership Styles on Libraries, Ph.D Dissertation. United States: Capella University.

Rowold, J. dan Rohmann, A. 2009."Relationships Between Leadership Style and Followers' Emotional experience and effectiveness in the voluntary sector. Dalam Nonprofit and Voluntary Sector Quarterly, volume 38, Nomor 20. $\mathrm{Hal} 271$.

Santoso, Djoko, 2012. "Dukungan Dikti Dalam Mewujudkan Universitas Riset di Indonesia". Dalam http://www.kopertis12.or.id/wp-content/ uploads/2012/10/2012-09-12-dikti.pdf. Tanggal 27 Juli 2017. Pukul 27 Juli 2017. Pukul 08.15

Siswadi, Irman. 2009. "Perpustakaan Sebagai Mata Rantai Komunikasi IImiah" Dalam Visi Pustaka, Volume 11, No 1. Dalam http://www. perpusnas.go.id/magazine/perpustakaan-sebagai-mata-rantai-komunikasi-ilmilah-scholarly-communication/. Tanggal 14 Juli 2017. Pukul 10.32.

Sugiyanti, Umi. 2012. Gaya Kepemimpinan Penanggungjawab Perpustakaan Dalam Mendukung Pengembangan Kualitas Pelayanan Perpustakaan (tesis), Yogyakarta: Sekolah Pasca Sarjana UGM.

Vickery, Brian dan Alina Vickery. 1987. Information Science in Theory and Practice, London: Butterworths. 